MATHEMATICA

CENTER FOR

STUDYING DISABILITY POLICY

DRC, Workino PAPER

WORKING PAPER NUMBER: 2014-04

Bridging the Gap: A Comparative Assessment of Vocational Rehabilitation Agency Practices with Transition-Age Youth

\title{
April 2014
}

\section{Todd Honeycutt *}

Maura Bardos

Stephanie McLeod

\section{*Corresponding author's contact information:}

Mathematica Policy Research

P.O. Box 2393

Princeton, NJ 08543

Telephone: (609) 945-3397

http://www.disabilitypolicyresearch.org/DRC/

Reference Number: MPR13-5

The research reported herein was pursuant to a grant from the U.S. Social Security Administration (SSA) funded as part of the Disability Research Consortium (DRC). The findings and conclusions expressed are solely those of the author(s) and do not represent the views of SSA or any agency of the Federal Government. 
This page has been left blank for double-sided copying. 


\section{CONTENTS}

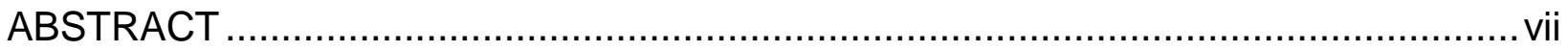

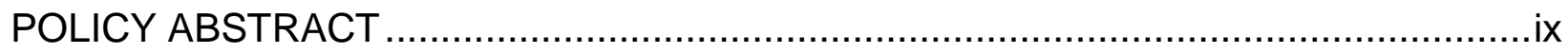

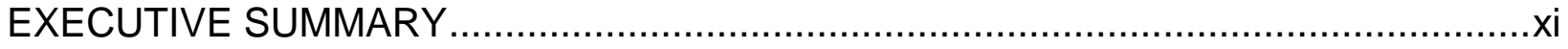

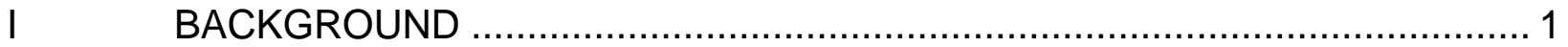

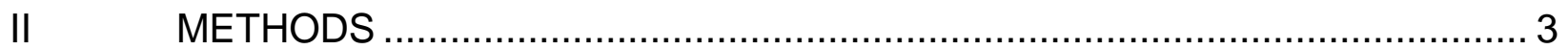

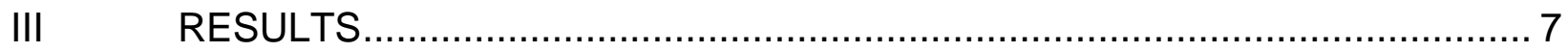

A. Organization and Collaboration ……............................................... 7

1. Themes Regarding Organization and Collaboration.......................... 7

2. Organizational and Collaborative Features Associated with Transition Ratios ......................................................................... 10

B. Outreach, Application, and Eligibility Processes ................................... 10

1. Themes Regarding Outreach, Application, and Eligibility Processes........................................................................... 10

2. Outreach, Application, and Eligibility Features Associated with Transition Ratios ................................................................... 13

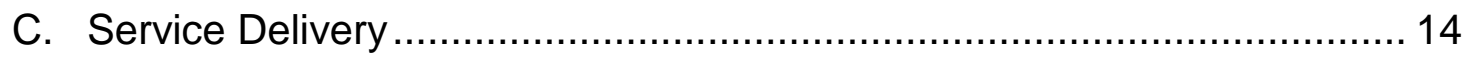

1. Themes Regarding Service Delivery ............................................. 14

2. Service Delivery Features Associated with Transition Ratios............ 16

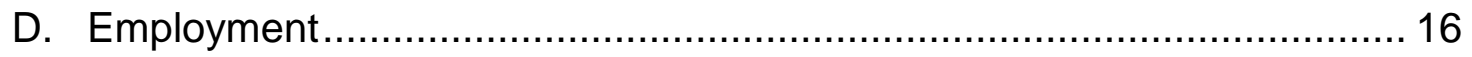

1. Themes Regarding Employment .............................................. 16

2. Employment Features Associated with Transition Ratios................. 18

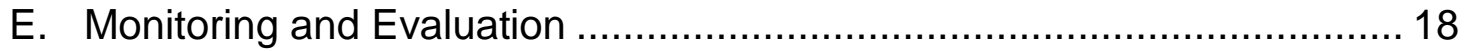

1. Themes Regarding Monitoring and Evaluation............................... 19

2. Monitoring and Evaluation Features Associated with

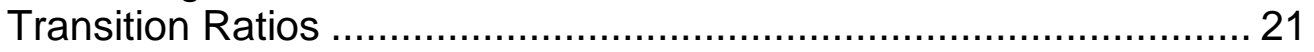


IV CONCLUSION 23

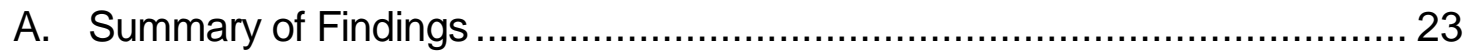

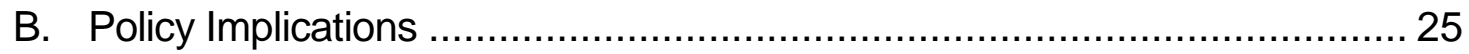

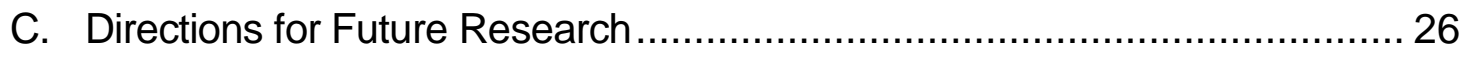

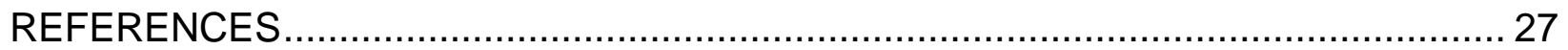




\section{TABLES}

$1 \quad$ Types and Number of Interviews Conducted with Each Agency .................. 4

2 Characteristics of VR Agencies on Organization and Collaboration.............. 8

3 Characteristics of VR Agencies on Outreach, Application, and Eligibility Processes...................................................................... 11

4 Characteristics of VR Agencies on Service Delivery .......................... 15

$5 \quad$ Characteristics of VR Agencies on Employment ............................. 17

$6 \quad$ Characteristics of VR Agencies on Evaluation and Monitoring

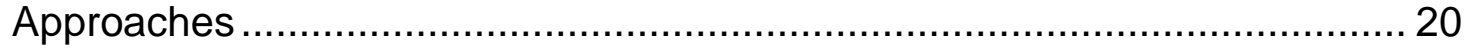

7 Summary of Features Differentiating Agencies with High and Low 
This page has been left blank for double-sided copying. 


\begin{abstract}
State vocational rehabilitation (VR) agencies are uniquely positioned to help youth with disabilities bridge the gaps in their transition to adulthood. This study explores the variation in VR agency practices with youth with disabilities using a case study approach for a select group of eight agencies-five of which had statistics for their youth applicants that indicated relatively higher transition outcomes compared to all agencies and three of which that did not. We conducted an indepth examination of five areas of VR agency practices: organization and collaboration strategies; outreach, application, and eligibility; service delivery; employment; and monitoring and evaluation. The eight agencies had many similarities in how they identified youth with disabilities and provided services to them, such as having staff dedicated to serving youth and having programs targeting youth, often in conjunction with one or more community partners. We also observed many differentiating features among agencies with high or low transition outcomes, some aspects less under an agency's control (such as being involved in local or statewide stakeholder collaborations) and other aspects within an agency's control (such as having state leadership with exclusive transition responsibilities and developing outreach to parents). Additional features, although within an agency's control, represent a greater resource cost; these include developing intensive school-based programs, enrolling more youth at earlier ages, and implementing programs to connect youth to postsecondary schools. Information on varying characteristics among VR agencies could help Rehabilitation Services Administration and VR agency administrators identify promising practices in serving transition-age youth with disabilities.
\end{abstract}


This page has been left blank for double-sided copying. 


\section{POLICY ABSTRACT}

For youth and young adults (ages 16 to 24) with disabilities making the transition from school to work, this passage can be filled with additional educational and vocational barriers beyond those for youth without disabilities. State vocational rehabilitation (VR) agencies are uniquely positioned to help youth with disabilities bridge the gaps in their transition to adulthood. This study identified 15 practices that differentiated agencies with high and low transition outcomes. For some practices, agencies have little control (such as being involved in local or statewide stakeholder collaborations). Others, though, are within an agency's control, with some requiring less effort (such as having state leadership with exclusive transition responsibilities and developing outreach to parents) and others representing a greater resource cost (such as developing intensive school-based programs, enrolling more youth at earlier ages, and implementing programs to connect youth to postsecondary schools). Though several practices were identified as promising, it is possible, and perhaps likely, that it is not one or another specific practice that helps youth, but a combination of factors (such as counselors, programs, and quality monitoring approaches) that together reflect an agency's commitment to serving youth. An overarching concern is whether policymakers should ask or require all agencies to implement some or all of the practices as part of their efforts to promote more successful transitions. Policymakers should consider the goals they are trying to achieve, both with their transition-age and general populations and with the environment and resources, before implementing any new policy. 
This page has been left blank for double-sided copying. 


\section{EXECUTIVE SUMMARY}

The road to adulthood can be a challenging time for a young person. For youth and young adults (ages 16 to 24) with disabilities making the transition from school to work, this passage can be filled with additional educational and vocational barriers beyond those for youth without disabilities. State vocational rehabilitation (VR) agencies are uniquely positioned to help youth with disabilities bridge the gaps in their transition to adulthood. VR agencies are joint federal-state programs that assist those eligible for rehabilitation services in attaining employment. Youth ages 16 to 24 make up a substantial portion of VR cases; from 2004 to 2011, about one-third of VR clients who achieved closure were in this age cohort when they applied for services.

In the current study, we explored the variation in VR agency practices for youth with disabilities for a select group of eight agencies - five of which had relatively high transition statistics and three of which did not. We conducted an in-depth examination of five areas of VR agency practices: organization and collaboration strategies; outreach, application, and eligibility; service delivery; employment; and monitoring and evaluation. Further, we compared the characteristics of agencies with high and low transition statistics to determine which factors, if any, differentiate the two groups. Each area reflects how VR agencies operate internally and coordinate with other state, local, and federal programs. We drew the information primarily from interviews with agency staff knowledgeable about transition issues, supplemented with data from Rehabilitation Services Administration (RSA) monitoring reports, RSA-911 case service records, and the agencies' annual reports to RSA.

\section{Key Findings}

The eight agencies had many similarities in how they identified youth with disabilities and provided services to them. Each had staff dedicated to serving youth, counselors assigned to work in specific schools, and processes for in-school work. They had developed multiple-and creative-ways to conduct outreach to schools and in-school youth. Each had developed programs targeting youth, often in conjunction with one or more community partners. Most recognized that they cannot serve all youth who qualify for education services under the Individuals with Disabilities Education Act (IDEA) or Section 508 of the Rehabilitation Act of 1973.

Despite these similarities, we observed many differentiating features among agencies with high and low transition ratios. As summarized in Table ES1, there are 15 such characteristics across the five areas that we considered. Some aspects are less under an agency's control, such as being under a state department of education and being involved in local or statewide stakeholder collaborations. Others are within an agency's control and could be more easily developed; examples include having state leadership with exclusive transition responsibilities and developing outreach to parents. Finally, some features, although within an agency's control, represent a greater resource cost; these include developing intensive school-based programs, enrolling more youth at earlier ages, and implementing programs to connect youth to postsecondary schools. 
Table ES1. Summary of Features Differentiating Agencies with High and Low Transition Ratios

\begin{tabular}{|c|c|c|c|c|c|c|c|c|}
\hline & \multicolumn{5}{|c|}{ Agencies with High Transition Ratios } & \multicolumn{3}{|c|}{ Agencies with Low Transition Ratios } \\
\hline & Agency A & Agency B & Agency C & Agency D & Agency E & Agency F & Agency G & Agency $\mathrm{H}$ \\
\hline \multicolumn{9}{|l|}{ Organization and Collaboration } \\
\hline $\begin{array}{l}\text { State organization placement in education } \\
\text { departments }\end{array}$ & $x$ & $x$ & & & $x$ & & & $x$ \\
\hline State leadership with transition responsibilities & $x$ & & & $x$ & $x$ & & & $x$ \\
\hline More stakeholder collaborations & & $\begin{array}{l}\text { State and } \\
\text { local }\end{array}$ & Local & $\begin{array}{l}\text { State and } \\
\text { local }\end{array}$ & Local & & & Local \\
\hline \multicolumn{9}{|l|}{ Outreach, Application, and Eligibility Processes } \\
\hline Outreach plans and activities that target parents & $x$ & $x$ & $x$ & $x$ & & & & \\
\hline Outreach plans and activities for out-of-school youth & $x$ & & $x$ & $x$ & $x$ & & & \\
\hline Targeting younger students for transition services & Sophomore & Sophomore & Junior & Junior & Junior & Junior & Senior & Junior $^{a}$ \\
\hline $\begin{array}{l}\text { Above-median scores for applicants ages } 16 \text { to } 24 \\
\text { who applied by age } 18\end{array}$ & $x$ & $x$ & & $x$ & $x$ & & & $x$ \\
\hline $\begin{array}{l}\text { Above-median scores for applicants ages } 16 \text { to } 19 \\
\text { with an IEP }\end{array}$ & $x$ & & & $x$ & $x$ & & & \\
\hline $\begin{array}{l}\text { Above-median scores for proportion of case closures } \\
\text { accounted for by transition-age youth }\end{array}$ & $x$ & $x$ & & $x$ & & & & \\
\hline \multicolumn{9}{|l|}{ Service Delivery } \\
\hline Intensive, school-based programs & $x$ & $x$ & $x$ & & & & & $x$ \\
\hline Connecting youth to postsecondary education & $x$ & & $x$ & $x$ & & & $x$ & \\
\hline Internal benefits counseling & $x$ & & $x$ & $x$ & $x$ & & & \\
\hline \multicolumn{9}{|l|}{ Employment } \\
\hline $\begin{array}{l}\text { Supporting employment programs other than Project } \\
\text { SEARCH }\end{array}$ & $x$ & $x$ & $x$ & $x$ & $x$ & & & $x$ \\
\hline \multicolumn{9}{|l|}{ Monitoring and Evaluation } \\
\hline Varied performance benchmarks for counselors & $x$ & & $x$ & $x$ & & & $x$ & \\
\hline Monitoring of youth-specific programs & $x$ & & $x$ & $x$ & $x$ & & & $x$ \\
\hline
\end{tabular}

a Senior at the time of the transition ratio analysis.

IEP = individualized education plan. 
Also notable are some features not listed in Table ES1, though they are considered by experts as key factors in promoting transitions. These include having counselors and staff who exclusively serve transition-age youth, having resource limitations associated with order of selection status, and offering employment programs and experiences. These factors, though important, might not be relevant to or practiced by the agencies studied. Alternatively, some factors might be necessary but not sufficient to promote higher transition ratios. For example, all agencies, even those with low transition ratios, had employment programs, often with multiple sites. However, many of these programs serve a small number of youth each, usually no more than 15 to 20 individuals. These intensive programs are likely useful for those who attend, though few of an agency's youth can attend.

An overarching concern is whether policymakers should ask or require all agencies to implement some or all of the program features listed in Table ES1 as part of their efforts to promote more successful transitions. Transferring policies, programs, and practices requires careful consideration of what is being transferred, the environment and actors involved, and the rationale for the transfer, and policymakers should consider the goals they are trying to achieve, both with their transition-age and general populations and with the environment and resources, before implementing any new policy.

\section{Policy Implications}

Several policy implications follow from the current study. First, 15 characteristics or practices were associated with agencies that had high transition ratios. Many of these are similar to best practices cited elsewhere, such as the VR Transition Study or Guideposts for Success. Use of these practices, inasmuch as agencies have control over them, may help youth with disabilities bridge the gap to adulthood.

Second, it is possible, and perhaps likely, that it is not one or another specific practice that helps youth, but a combination of factors (such as counselors, programs, and quality monitoring approaches) that together reflect an agency's commitment to serving youth. This commitment might also indicate the community's desires to promote transition or the level of resources to which an agency has access. For instance, the fact that agencies with higher transition ratios have state- or community-level collaborations with various stakeholders on transition issues could result from the community's commitment to serving these youth, which the agency is capitalizing on, but not leading.

A third policy implication involves monitoring. RSA currently presents metrics for transition-age youth as part of its reports for VR agencies, but those metrics reflect the adult populations that agencies serve. Agency staff seek guidance on the definition of transition-age youth, appropriate measures that reflect the goals and needs of these youth, and standards by which to measure services and success. Recent changes to the RSA-911 data provided by state agencies—on youth educational enrollment, involvement with other providers, and postsecondary education, for example_could potentially be used to develop appropriate outcome measures for this population. 
This page has been left blank for double-sided copying. 


\section{BACKGROUND}

The road to adulthood can be a challenging time for a young person. For youth and young adults (ages 16 to 24) with disabilities making the transition from school to work, this passage may be filled with additional educational and vocational barriers beyond those for youth without disabilities. This transition may be further complicated for individuals who are first diagnosed as young adults with psychiatric or other severe mental illnesses. Overall, youth with disabilities have lower high school graduation rates than their peers without disabilities and also lag behind their peers in terms of employment (Sanford et al. 2011; U.S. Department of Education 2010). Employment and education barriers are particularly significant for youth receiving child Supplemental Security Income (SSI) benefits (Hemmeter et al. 2009; Loprest and Wittenburg 2007). These poor outcomes show that human capital development continues to be a challenge for youth with disabilities as they enter adulthood.

While institutional and community level supports exist to help youth with disabilities make the transition to adulthood, those who navigate the support system often experience difficulties (Luecking and Wittenburg 2009; Moreno et al. 2013; Wittenburg, Golden, and Fishman 2002). Small, localized programs, such as Project SEARCH (Rutkowski et al. 2006), can help youth have successful transitions, but they tend to serve very small numbers of youth. In most cases, youth with disabilities depend on school-based services, historically the main provider of school-to-work transition services to this group. ${ }^{1}$ Schools may offer an array of vocational services, but youth participation and involvement in these services can vary widely, and those programs that are most promising for youth, such as job placement and mentorship programs, are not offered frequently (Carter et al. 2010). In addition, reliance on school-based services is problematic for youth with disabilities who either leave high school (whether from graduation or dropping out) or are ineligible for secondary school transition planning under the Individuals with Disabilities Education Act (IDEA). Further, the support system for adults is largely fragmented, with providers often having different and varied eligibility requirements. The difficulty of accessing these adult supports is compounded for youth by a lack of coordination between school- and adult-based services as youth leave secondary school (Luecking and Certo 2003; U.S. Government Accountability Office 2006; Wittenburg, Golden, and Fishman 2002).

State vocational rehabilitation (VR) agencies are uniquely positioned to help youth with disabilities bridge the gaps in their transition to adulthood. VR agencies are joint federal-state programs that assist those eligible for rehabilitation services in attaining employment. Youth ages 16 to 24 make up a substantial portion of VR cases; from 2004 to 2011, 32 percent of VR clients who attained closure had been between these ages when they applied for services (based on authors' calculations of Rehabilitation Services Administration [RSA]-911 data). Many agencies have recognized the special needs of youth and have focused their efforts on easing the transition from school to work or postsecondary education. VR agencies are required to collaborate with state

${ }^{1}$ Under the Individuals with Disabilities Education Act, school district staff develop individualized education plans (IEPs) for eligible students with disabilities, with the input of those students, to help assist them in addressing their needs. Transition planning aimed at promoting independent living, postsecondary education, and access to other services might also be a part of the IEP process to promote postschool transitions (Aron and Loprest 2012; Wittenburg et al 2002). 
education agencies to plan and deliver services to students with disabilities. As a result of those collaborations, VR can intervene while the youth is still in school by attending individualized education plan (IEP) meetings and facilitating entry into job training programs. Youth can also benefit from VR services such as specialized training, soft skill development, and financing and other supports for postsecondary education. For youth who are eligible and initiate the process, VR staff develop a service plan aimed at achieving competitive, paid employment and provide services to help the individual attain that goal. VR agency staff often have connections, either formally or informally, with American Job Centers (formerly One-Stop Centers), Centers for Independent Living (CILs), state agencies, and other community-based organizations. Through these relationships, VR can educate clients about community services and facilitate program entry.

An earlier study using RSA-911 data indicated large variation among VR agencies on key outcome domains of outreach, receipt of services, and employment for youth (Honeycutt et al. 2013). That study examined the experiences of individuals ages 16 to 24 who applied for services in 2004, 2005, and 2006. Nationwide, 8 percent of youth with disabilities applied for VR services in those years, ranging from a low of 4 percent to a high of 14 percent across states. Of those who applied, 56 percent eventually received services, ranging from 31 percent to 82 percent. Finally, 56 percent of cases served had a successful employment outcome, with states varying from 40 to 70 percent. Multiplying these three ratios produces a summary ratio indicating the proportion of youth with disabilities who applied to VR, received services, and closed with employment. Nationwide, the summary ratio was 2.3 percent; states ranged from less than 1 percent to almost 7 percent.

In the current study, we explored the variation in VR agency practices with youth with disabilities for a select group of eight agencies-five of which had transition ratios that were relatively high and three of which did not. We conducted an in-depth examination of five areas of VR agency practices: organization and collaboration strategies; outreach, application, and eligibility; service delivery; employment; and monitoring and evaluation. Further, we compared the characteristics of agencies with high and low transition statistics to determine which factors, if any, differentiate the two groups. Each area reflects how VR agencies operate internally and coordinate with other state, local, and federal programs. Information on varying characteristics among VR agencies could help RSA and VR agency administrators identify promising practices in serving transition-age youth with disabilities. 


\section{METHODS}

In this study, we drew on structured interviews with VR agency staff on their current practices serving youth with disabilities. We selected eight agencies that varied in size, local environments, and geographic region, though all had an emphasis on serving youth with disabilities. We analyzed the interview data across the five dimensions that are the focus of the study (organization and collaboration; outreach, application, and eligibility; service delivery; employment; and agency evaluation and monitoring). To identify potential best practices, we contrasted the experiences of five agencies that had higher values on transition-specific measures from our earlier study with the experiences of three agencies that had lower values. We present more details about our methods in the remainder of this section.

The first step in the analysis was to identify agencies for inclusion in the study sample. We used three criteria for selecting agencies:

1. Using findings from our earlier analysis (Honeycutt et al. 2013), we grouped agencies into categories based on the extent to which they served youth, which was determined using three transition ratios: the proportion of the state youth population with disabilities who applied for service, the proportion of applicants who received services from the agency, and the proportion of those served whose cases were closed with a positive employment outcome. We classified agencies as having either relatively high values (above the median for all state VR agencies) for these transition ratios or relatively low values (below the median). Our goal was to select five agencies with high values and three agencies with low values; although we do not present these values explicitly in order to maintain agency anonymity, we present results for agencies grouped by this categorization.

2. We selected only agencies that had an explicit emphasis on serving transition-age youth, as agencies without such an emphasis would be unlikely to yield relevant findings for the analysis. All state VR agencies are expected to provide services to youth with disabilities and to cooperate with secondary schools in working with youth as they approach graduation; however, agencies vary in the extent to which they focus on youth. We used two approaches to classify agencies along this dimension. First, using a review of agency service plans, we identified those agencies that reported having at least one goal or objective related to transition-age youth or at least one specialized program for transitionage youth. Second, we drew on the Vocational Rehabilitation Transition Study to identify agencies with at least one transition coordinator with statewide responsibilities or with counselors who had dedicated youth caseloads (The Study Group 2007). Agencies with either characteristic were considered to have a youth emphasis.

3. We also selected states with geographic and demographic variation. For geographic variation, we selected agencies in four regions (Midwest, West, South, and Northeast). For demographic variation, we chose agencies in states that varied by the number of annual applicants, economic condition (determined using state unemployment rates), client characteristics (race and ethnicity, disability type, and benefit status), resource levels (determined using order of selection [OOS] status and 2008 VR grant allotment), and the size of counselor caseloads.

Through this process, we identified eight agencies, five with high transition ratios and three with

low transition ratios. Two of the agencies we initially identified did not respond to requests to 
participate in the study, so we replaced them with two other agencies with similar ratios and characteristics.

After obtaining consent from the agency director or some other designated official, we interviewed two to four key informants from each state using a structured interview. ${ }^{2}$ With our input, administrative staff of the agencies selected individuals to participate in the interviews. As shown in Table 1, we interviewed various agency staff: VR agency directors, state-level transition coordinators or specialists, regional-level staff with management roles related to transition, local supervisors knowledgeable about transition issues, and VR counselors who were knowledgeable about transition issues and worked primarily with youth. We supplemented the data from the interviews with data from the RSA-113 or RSA-911 files as well as information from recent state VR service plans submitted to RSA.

Table 1. Types and Number of Interviews Conducted with Each Agency

\begin{tabular}{|c|c|c|c|c|c|c|c|c|}
\hline & \multicolumn{5}{|c|}{ Agencies with High Transition Ratios } & \multicolumn{3}{|c|}{$\begin{array}{c}\text { Agencies with Low Transition } \\
\text { Ratios }\end{array}$} \\
\hline & $\begin{array}{l}\text { Agency } \\
\text { A }\end{array}$ & $\begin{array}{l}\text { Agency } \\
\text { B }\end{array}$ & $\begin{array}{l}\text { Agency } \\
\text { C }\end{array}$ & $\begin{array}{l}\text { Agency } \\
\text { D }\end{array}$ & $\underset{\mathrm{E}}{\text { Agency }}$ & $\begin{array}{l}\text { Agency } \\
\mathrm{F}\end{array}$ & $\begin{array}{l}\text { Agency } \\
\text { G }\end{array}$ & $\underset{\mathrm{H}}{\text { Agency }}$ \\
\hline VR Agency Director & $\mathrm{x}$ & & & & & & $x$ & $\mathrm{x}$ \\
\hline State Administrator & $\mathrm{x}$ & $\mathrm{x}$ & $\mathrm{x}$ & $\mathrm{x}$ & $\mathrm{x}$ & $\mathrm{x}$ & $x(2)$ & $\mathrm{x}$ \\
\hline Responsible for & & & & & & & & \\
\hline Transition Issues & & & & & & & & \\
\hline Regional Transition & & & & $\mathrm{x}$ & & & & \\
\hline Coordinator & & & & & & & & \\
\hline Local Supervisor & $\mathrm{x}$ & $\mathrm{x}$ & & $\mathrm{x}$ & $\mathrm{x}$ & $\mathrm{x}$ & $\mathrm{x}$ & \\
\hline VR Counselor & $\mathrm{x}$ & $x$ & $X(2)$ & & & & & $\mathrm{x}$ \\
\hline Number of Interviewees & 4 & 3 & 3 & 3 & 2 & 2 & 4 & 3 \\
\hline
\end{tabular}

Our analysis of the interview data involved four steps. First, we developed a series of tables with multiple categories displaying agency characteristics in each of five dimensions. Second, each author independently reviewed the interview notes and coded the responses. We then reviewed each other's coding and resolved disagreements by reading the interview notes again or collecting additional information from interviewees. Third, we simplified the tables by collapsing agency characteristics into a few broad categories for each dimension; we present this information in the results section of this report. Fourth, we contrasted the characteristics of agencies with high and low transition ratios. We identify promising practices as those commonly used by agencies with high transition ratios and rarely or never used by those with low transition ratios.

One concern regarding this analytical approach is that we are contrasting current agency practices based on historical transition ratios. Our analysis of transition ratios was for cohorts of VR youth applicants in 2004 through 2006 and used RSA-911 records from fiscal year (FY) 2004 through FY 2011. The processes employed by agencies during those years could differ from an agency's processes at the time that we conducted our interviews. In particular, one agency with a low transition ratio (Agency $\mathrm{H}$ ) reported making many recent changes to its processes in response to its

2 We appreciate the assistance of the Council of State Administrators of Vocational Rehabilitation (CSAVR) assistance with encouraging VR agencies' participation in the study. 
outcomes for youth being below expectations. These changes included working with youth at earlier ages, using data to identify areas in which services were needed, and tracking milestone achievements for clients. The structure of the RSA-911 data (which includes only those cases that were closed in the given year) will not allow us to replicate the same analyses on a cohort of youth who applied in the year we conducted our interviews (2013) until at least the FY 2017 data are released.

As a check on the consistency of these states' transition ratios over time, we used FY 2011 data (the most recent data available) to examine statistics for recent closures. With this approach, we were able to calculate two of three ratios from the earlier study: the proportion of transition-age applicants who received services and the proportion of those who received services who had a positive employment outcome. All three agencies with below-median values for these two ratios in our earlier analysis also had below-median values in the FY 2011 data. Furthermore, four of the five high-ratio agencies we had identified also showed higher than median values of these ratios in FY 2011, while the fifth was above the median in one of the two ratios. This pattern suggests that agency ratios for youth VR applicants were similar for the period of our original analysis and the period when we conducted interviews. We conclude that our approach to contrasting practices according to agency transition ratios is appropriate and informative.

We used information from the interviews to identify promising practices in serving youth that could be adopted by other VR agencies or incorporated into current and alternative programs for youth with disabilities. We mask the identification of the state VR agencies in this report in order to preserve their confidentiality. In the sections below, we identify the agencies by the letters A though $\mathrm{H}$ and group them by whether their transition ratios were above or below the median values. 
This page has been left blank for double-sided copying. 


\section{RESULTS}

\section{A. Organization and Collaboration}

Due to historical developments and differing state environments, VR agencies have a range of organizational and staffing structures. Though agencies are often embedded in state education departments, some are part of departments of workforce or labor or are standalone entities. Many agencies have staff who exclusively serve youth and operate in schools, while others require that staff serve both adults and youth. Collaborations on transition issues can range from statewide initiatives involving other state agencies and key community organizations to local meetings involving schools and other partners that consider ways to improve transition outcomes or discuss the needs of individual youth. These collaborations may or may not involve shared funding, staff, space, or other resources between the VR agency and partner organizations.

\section{Themes Regarding Organization and Collaboration}

In examining the structural and environmental issues for VR agencies and transition-age youth (see Table 2), we found the following themes:

- State organizational placement. Four agencies were embedded in state departments of education. Agency staff mentioned two key advantages of this structure: closer ties with secondary schools and access to education-related data. Two other agencies were tied to departments of labor, one was tied to a rehabilitation department, and one was an independent entity.

- Transition staffing. We collected information on two types of transition staff. The first involved agency leadership-did the agency have at least one administrative-level position with an exclusive focus on transition issues? Four agencies did; four others had administrators for whom transition issues were one aspect of their jobs. The second involved counselors whose entire caseload was exclusively devoted to transition-age youth. An advantage of this arrangement is that the counselor can develop close ties with secondary schools and their staff and develop their skills in working with youth. While six agencies had at least some transition counselors, just two of those six had many counselors focused on transition. Other agencies had just a few such counselors, primarily located in urban or highly populous settings. Though staff often reported a preference for having transition counselors, the number of youth served by an office was often too small to justify that allocation of resources-particularly in rural settings or states with smaller populations. Two agencies (D and $\mathrm{H}$ ) also had transition specialists at the office or district level whom counselors could contact for additional transition support. 
Table 2. Characteristics of VR Agencies on Organization and Collaboration

\begin{tabular}{|c|c|c|c|c|c|c|c|c|}
\hline \multirow[b]{3}{*}{$\begin{array}{l}\text { State Organizational } \\
\text { Placement }\end{array}$} & \multicolumn{5}{|c|}{ Agencies with High Transition Ratios } & \multicolumn{3}{|c|}{ Agencies with Low Transition Ratios } \\
\hline & Agency A & Agency B & Agency C & Agency D & Agency E & Agency F & Agency G & Agency $\mathrm{H}$ \\
\hline & Education & Education & Other & Other & Education & Other & Other & Education \\
\hline \multicolumn{9}{|l|}{ Transition Staffing } \\
\hline $\begin{array}{l}\text { State leadership with only } \\
\text { transition responsibilities }\end{array}$ & $x$ & & & $x$ & $x$ & & & $x$ \\
\hline Transition counselors & & Limited & Numerous & Limited & Limited & Limited & Limited & Numerous \\
\hline $\begin{array}{l}\text { County or office-level } \\
\text { transition specialists }\end{array}$ & & & & x & & & & x \\
\hline \multicolumn{9}{|l|}{ Funding Sufficiency } \\
\hline $\begin{array}{l}\text { OOS status (at time of } \\
\text { interview) }\end{array}$ & oOs & No OOS & No OOS & oOs & No OOS & No OOS & oOs & oOs \\
\hline $\begin{array}{l}\text { Wait list for services (at time } \\
\text { of interview) }\end{array}$ & $\begin{array}{l}\text { Wait list for } \\
\text { individuals with } \\
\text { less severe } \\
\text { disabilities }\end{array}$ & No wait list & No wait list & No wait list & No wait list & No wait list & Wait list & $\begin{array}{l}\text { Wait list for } \\
\text { individuals with } \\
\text { less severe } \\
\text { disabilities }\end{array}$ \\
\hline $\begin{array}{l}\text { OOS status (at time of } \\
\text { transition ratio calculation) }\end{array}$ & oos & oOs & No OOS & oOs & No OOS & No OOS & oOs & No OOS \\
\hline $\begin{array}{l}\text { Wait list for services (at time } \\
\text { of transition ratio } \\
\text { calculation) }\end{array}$ & Wait list & No wait list & No wait list & Wait list & No wait list & No wait list & Wait list & No wait list \\
\hline \multicolumn{9}{|l|}{$\begin{array}{l}\text { Collaboration on Transition } \\
\text { Issues }\end{array}$} \\
\hline Stakeholder collaboration & & State and local & Local & State and local & Local & & & Local \\
\hline $\begin{array}{l}\text { Agreements with education } \\
\text { departments or school } \\
\text { districts involving shared } \\
\text { funding }\end{array}$ & $x$ & & $x$ & $\mathrm{x}$ & & $x$ & $x$ & $x$ \\
\hline $\begin{array}{l}\text { Agreements with other } \\
\text { agencies involving shared } \\
\text { resources }\end{array}$ & $\begin{array}{l}\text { One program } \\
\text { (postsecondary } \\
\text { institutions) }\end{array}$ & No programs & $\begin{array}{c}\text { Multiple } \\
\text { programs } \\
\text { (juvenile justice, } \\
\text { postsecondary } \\
\text { institutions, } \\
\text { developmental } \\
\text { disability } \\
\text { agency) }\end{array}$ & $\begin{array}{c}\text { Multiple } \\
\text { programs } \\
\text { (community } \\
\text { organizations, } \\
\text { postsecondary } \\
\text { institutions, } \\
\text { juvenile justice } \\
\text { system, adult } \\
\text { development } \\
\text { and } \\
\text { developmental } \\
\text { disability } \\
\text { offices) }\end{array}$ & $\begin{array}{c}\text { Multiple } \\
\text { programs } \\
\text { (developmental } \\
\text { disability } \\
\text { agency, Center } \\
\text { for Independent } \\
\text { Living, } \\
\text { community } \\
\text { organizations, } \\
\text { postsecondary } \\
\text { institution) }\end{array}$ & $\begin{array}{l}\text { One program } \\
\text { (community } \\
\text { organizations, } \\
\text { postsecondary } \\
\text { institution) }\end{array}$ & $\begin{array}{c}\text { Multiple } \\
\text { programs } \\
\text { (postsecondary } \\
\text { institution, } \\
\text { county } \\
\text { developmental } \\
\text { disability } \\
\text { agencies, } \\
\text { various other } \\
\text { organizations) }\end{array}$ & $\begin{array}{c}\text { Multiple } \\
\text { programs } \\
\text { (community } \\
\text { organizations, } \\
\text { postsecondary } \\
\text { institutions) }\end{array}$ \\
\hline
\end{tabular}

OOS $=$ order of selection 
- Funding sufficiency. An agency's being in OOS can be detrimental for all individuals seeking VR services, but can particularly hamper youth in obtaining timely services to assist in the school-to-work transition. Four agencies were in OOS at the time of our interviews, and three of them had wait lists for services for at least some applicants, with waiting times ranging from seven months to two years. While youth with the most severe disabilities were reportedly served without delay in all agencies selected for the study, those with less severe disabilities may have to wait many months — or never even be served-due to resource limitations. As an example of a creative solution to this issue, staff from one agency asked youth to apply in their sophomore year, so that they could begin receiving services their junior year. For the group of youth for whom transition ratios were calculated (applicants from 2004 to 2006), four agencies were in OOS at the time, three of which had wait lists for services. Five agencies were similar in their OOS status both in the years for which transition ratios were calculated and at the time of the interview; Agencies A and G were in OOS with wait lists in both periods; and Agencies $\mathrm{C}, \mathrm{E}$, and $\mathrm{F}$ were not in OOS in either period. From a more subjective standpoint, staff from four agencies reported that their agency did not have the capacity to serve all youth with disabilities within the state. Those agencies provide services to a small portion of all youth with disabilities who might be in need of assistance.

\section{- Collaboration on transition issues}

- Stakeholder collaboration. Many communities had local or state-level efforts to promote transition efforts among multiple stakeholders. In Agency D, for instance, some counties had workgroups involving local stakeholders, such as staff from the VR agency, providers, and schools as well as family members, who met often to discuss transition issues and plan events for youth. VR staff use these meetings to present and obtain feedback on their own initiatives. These collaborations may not take place across the entire state, however. Statewide efforts included initiatives such as multiple state agencies developing agreements to promote information sharing and improved collaboration on transition issues.

- Agreements with education departments or school districts involving shared funding. RSA requires that each VR agency have an agreement with the state department of education delineating the entities' roles and responsibilities with respect to serving students with disabilities. We assessed whether the agencies had more involved relationships with their education departments or local school districts-defined as formal agreements that include projects with joint or shared funding. Six agencies had such agreements. As an example, Agency $\mathrm{C}$ and local schools both contributed funding for special school-based transition programs to provide additional staff and resources for youth.

- Agreements with other agencies involving shared resources. We found less evidence of formal agreements involving shared resources with organizations other than state departments of education. Though many VR staff reported working with other organizations through referrals or sharing information, staff reported fewer instances of other organizations contributing resources. Agencies $\mathrm{A}$ and $\mathrm{F}$, for instance, reported just one collaborative program with such an organization. Five agencies, though, reported multiple programs involving several types of organizations. Agency D, for instance, had developed several programs with postsecondary schools to engage youth with disabilities, partnered with state organizations (such as the juvenile justice system) for outreach, and 
developed pilot programs with disability-specific state organizations along with community-based organizations (CBO).

Two significant gaps emerged in our discussions with staff about the types of collaborations they had. First, there was a lack of strong involvement with American Job Centers; though some agencies had ties to these sites for their adult clients, none had formal arrangements with Job Centers regarding transition-age youth. Second, no agency staff reported strong connections with local SSA field offices. Though staff discussed referring youth and families to field offices or having benefits counselors involved with SSA (see below), we received no reports of involvement or programs with SSA staff.

\section{Organizational and Collaborative Features Associated with Transition Ratios}

Three organizational and collaboration features differed across agencies with high and low transition ratios:

- State organizational placement in education departments. Most agencies with high transition ratios (three of five) were located in an education-related department; that was true of only one of three agencies with low transition ratios.

- State leadership with transition responsibilities. Agencies with high transition ratios more frequently (three of five) had statewide administrators dedicated to transition than did agencies with low transition ratios (one of three).

- More stakeholder collaborations. Four of five agencies with high transition ratios engaged in statewide or local collaboration initiatives or working groups with external agencies (perhaps reflecting the focus of the larger community); just one agency with low transition ratios did.

\section{B. Outreach, Application, and Eligibility Processes}

VR agencies use varying strategies to identify and engage transition-age youth. While agencies must align with certain standards put forth by the federal government regarding performance and services, they have latitude to customize their outreach, application, and eligibility processes.

\section{Themes Regarding Outreach, Application, and Eligibility Processes}

VR agencies reported a number of different outreach activities aimed at those enrolled in secondary school (referred to as in-school) and those who are not (referred to as out-of-school, which includes those enrolled in postsecondary institutions), as well as their families (see Table 3). The intensity of outreach and enrollment activities varied widely among agencies.

- Outreach plans and activities for secondary school youth. Outreach activities for inschool youth were conducted within secondary schools with both students and teachers. Activities included communicating with school staff, visiting classrooms, developing transition guides, and attending IEP meetings and parent-teacher conferences. Half of the agencies interviewed also conducted or participated in outreach fairs aimed at reaching transition-age youth (which could include out-of-school youth). Outreach activities targeting parents and families were mentioned by staff in four agencies. One agency provided outreach to alternative schools, such as home schools and charter schools. 
Table 3. Characteristics of VR Agencies on Outreach, Application, and Eligibility Processes

\begin{tabular}{|c|c|c|c|c|c|c|c|c|}
\hline & \multicolumn{5}{|c|}{ Agencies with High Transition Ratios } & \multicolumn{3}{|c|}{ Agencies with Low Transition Ratios } \\
\hline & Agency A & Agency B & Agency C & Agency D & Agency E & Agency F & Agency G & Agency H \\
\hline $\begin{array}{l}\text { Outreach Plans and } \\
\text { Activities for Secondary } \\
\text { School Youth }\end{array}$ & $\begin{array}{l}\text { School staff, } \\
\text { parents }\end{array}$ & $\begin{array}{l}\text { School staff, } \\
\text { fairs, parents }\end{array}$ & $\begin{array}{l}\text { School staff, parents, } \\
\text { alternative schools }\end{array}$ & $\begin{array}{l}\text { Annual } \\
\text { conference, } \\
\text { parents, } \\
\text { transition fairs }\end{array}$ & School staff & $\begin{array}{l}\text { Fairs, school } \\
\text { staff }\end{array}$ & $\begin{array}{l}\text { Transition } \\
\text { guide for } \\
\text { school staff }\end{array}$ & $\begin{array}{l}\text { School staff, } \\
\text { fairs }\end{array}$ \\
\hline $\begin{array}{l}\text { Outreach Plans and } \\
\text { Activities for Out-of-School } \\
\text { Youth }\end{array}$ & $\begin{array}{l}\text { State agencies } \\
\text { serving youth; } \\
\text { GED programs } \\
\text { at } \\
\text { postsecondary } \\
\text { institutions }\end{array}$ & $\begin{array}{l}\text { None (other than } \\
\text { transition fair) }\end{array}$ & $\begin{array}{l}\text { State agencies } \\
\text { serving youth; } \\
\text { connections to } \\
\text { disability offices at } \\
\text { postsecondary } \\
\text { schools; counselors } \\
\text { with exclusive } \\
\text { postsecondary } \\
\text { institution caseloads }\end{array}$ & $\begin{array}{l}\text { State agencies } \\
\text { serving youth; } \\
\text { postsecondary } \\
\text { programs }\end{array}$ & $\begin{array}{l}\text { Programs for } \\
\text { high school } \\
\text { dropouts }\end{array}$ & None & None & None \\
\hline Special Marketing Efforts & $\begin{array}{l}\text { Promotional } \\
\text { materials }\end{array}$ & Social networks & $\begin{array}{l}\text { Social networks, } \\
\text { promotional materials }\end{array}$ & $\begin{array}{l}\text { Promotional } \\
\text { materials }\end{array}$ & & Media outreach & $\begin{array}{l}\text { Promotional } \\
\text { materials }\end{array}$ & \\
\hline $\begin{array}{l}\text { Target Grade for Transition } \\
\text { Services }\end{array}$ & Sophomore & Sophomore & Junior & Junior & Junior & Junior & Senior & $\begin{array}{l}\text { Junior (Senior } \\
\text { at the time of } \\
\text { ratio analysis) }\end{array}$ \\
\hline $\begin{array}{l}\text { Percentage of Applicants } \\
\text { Ages } 16 \text { to } 24 \text { Who Applied } \\
\text { by Age } 18\end{array}$ & Above median & Above median & Below median & Above median & Above median & Below median & Below median & Above median \\
\hline $\begin{array}{l}\text { Percentage of Applicants } \\
\text { Ages } 16 \text { to } 19 \text { with an IEP }\end{array}$ & Above median & Below median & Below median & Above median & Above median & Below median & Below median & Below median \\
\hline $\begin{array}{l}\text { Percentage of All } 2004 \\
\text { Case Closures Accounted } \\
\text { for by Transition-Age Youth }\end{array}$ & Above median & Above median & Below median & Above median & Below median & Below median & Below median & Below median \\
\hline
\end{tabular}

GED = general educational development; IEP = individualized education plan . 
- Outreach plans and activities for out-of-school youth. Out-of-school youth are particularly hard to engage because of their mobility and lack of connections to the service system. However, staff from four agencies reported successful outreach efforts to this population, primarily by collaborating with other agencies serving youth. For example, one agency reported working with juvenile justice, developmental disability, and mental health agencies to reach out-of-school youth who were potentially eligible for services. Staff from three agencies reported working with postsecondary schools (including disability resource centers and agencies that provide general educational development classes) to identify youth.

- Special marketing efforts. Six agencies described special marketing efforts to reach transition-age youth. Three of these agencies used traditional means, such as brochures, informative publications, or other print materials. Three other agencies reported using innovative strategies involving social media. For example, one agency, in collaboration with the state department of education, developed an online video that allowed teachers, students, and families to learn about its services.

- Target grade for transition services. The majority of agencies engaged secondary school youth during their junior year. Two agencies engaged them in their sophomore year, and the eighth agency waited until the youths' senior year to begin working with inschool clients. ${ }^{3}$ While agencies differed in the target grade for planning, almost all agreed that early engagement was the best practice. Agencies reported that early engagement allows counselors to spend the maximum amount of time with a youth delivering services and preparing them for life after secondary school, resulting in better outcomes. The push towards early engagement may be a recent one. Two agencies reported that they had made policy changes to engage youth at a younger age or grade within the last five years; Agency $\mathrm{H}$ did so in response to data showing that its outcomes were below their targets, and Agency A did so in response to being in OOS.

All selected agencies reported similar approaches to working with schools to identify potential youth, and all reported that the eligibility criteria was similar to the criteria for the adult population; none had an expedited process for youth applicants. To gain additional insight into these processes, we calculated three statistics from the RSA-911 data related to the outreach, application, and eligibility process and compared each agency's value with the median value across all agencies (see Table 3).

- Percentage of applicants ages 16 to 24 who applied by age 18 (applicants from 2004 to 2006). This measure may indicate how well agencies reached youth before they left the secondary school system. (A low number could also indicate an agency with either strong outreach to out-of-school youth or a large portion of youth who remained in secondary schools until age 21.) Nationwide, 49 percent of youth who applied did so when they were age 18 or earlier; five agencies in this study had higher proportions of youth applicants.

3 The grade is relative to the youth's graduation time frame. Youth who qualify for education services under IDEA may stay in school until age 21, making their junior and senior years occur at older ages than for youth on a traditional track. 
- Percentage of applicants ages 16 to 19 with an IEP (applicants from 2004 to 2006). The proportion of youth with an IEP could reflect the extent to which VR staff collaborated with secondary schools, though this statistic is only valid if staff accurately record the IEP information. Agencies with higher values of this statistic may have stronger outreach and referral activities within secondary schools; those with lower values may have fewer connections with schools. Nationwide, the median value of this statistic was 75 percent; three agencies had values above the median.

- Percentage of all 2004 case closures accounted for by transition-age youth. The final statistic was the proportion of all case closures in 2004 who were transition age (16 to 24) at the time of their application. Values of this statistic reflect the overall size of the transition-age population relative to the general VR population. Potentially, agencies with higher values might have a tendency to provide more transition services and programs (and thus have higher transition ratios) because of greater demand. The median value of this statistic nationally was 30.8 percent (meaning that somewhat less than one-third of case closures involved transition-age youth). Three agencies in this study had values above the median. We also calculated this statistic for 2011 case closures and obtained the same results for the eight study agencies relative to the national median.

\section{Outreach, Application, and Eligibility Features Associated with Transition Ratios}

Agencies with high and low transition ratios differed on many outreach, application, and eligibility features:

- Outreach plans and activities targeted to parents. Four of five agencies with high transition ratios mentioned efforts to actively educate and involve parents; no agencies with low transition ratios did so.

- Outreach plans and activities for out-of-school youth. Four of five agencies with high transition ratios engaged in efforts to identify out-of-school youth for services. This was not the case with any of the agencies with low transition ratios.

- Targeting younger students for transition services. Two agencies with high transition ratios targeted youth in their sophomore years; one agency with a low transition ratio targeted youth in their senior years, and another did so for the period covered by the transition ratio analysis.

- Above-median percentage of applicants ages 16 to 24 who applied by age 18 . Four of five agencies with high transition ratios had an above-median percentage of youth who had applied by the time they were age 18 compared to one of three low ratio agencies.

- Above-median percentage of applicants ages 16 to 19 with an IEP. Based on RSA911 data, three of five agencies with high transition ratios had values above the national median for the proportion of youth ages 16 to 19 who had an IEP; none of the agencies with low transition ratios did.

- Above-median percentage of case closures accounted for by transition-age youth. Three of five agencies with high transition ratios had above-median percentages of all 2004 case closures accounted for by transition-age youth; none of the agencies with low transition ratios did. 


\section{Service Delivery}

Youth who are eligible for VR services and obtain an IPE can receive a range of services tailored to their vocational goals. These may include job coaching and placement, training on independent living skills, and funding for postsecondary education. In addition to these individualized services, our study agencies had implemented many programs to enhance or deliver services for youth, the most comprehensive being those conducted in secondary schools.

\section{Themes Regarding Service Delivery}

We summarize key aspects of service delivery for transition-age youth in Table 4. In some instances, a program fell into more than one category; we list each program just once.

- Secondary school programs. Six agencies operated programs in secondary schools. Four of these (Agencies A, B, C, and H) funded intensive, school-based programs for large numbers of youth in multiple high schools, under which youth could potentially receive yearround services through their senior year. All of these programs were developed in partnership with local schools. Two agencies $(\mathrm{C}$ and $\mathrm{H})$ had also developed programs, either funded entirely by VR or in cooperation with $\mathrm{CBOs}$, that provided vocational and career training focused in science, technology, engineering, and mathematics. A key advantage of all of these programs is the inclusion of special programming to keep youth engaged during the summer. One key component of two school-based programs was the potential to follow youth for a long period after VR closure (up to age 25, for example). The other two agencies (agencies E and F) that had secondary school programs served much smaller numbers of students.

- Independent living programs. Two agencies ran independent living programs for youth, helping youth develop skills such as cooking, driving, personal care, and money management. These programs also included employment or education curricula, though this was not a primary focus. These programs provided time-limited services to small numbers of youth.

- Postsecondary education programs. Four agencies had programs to promote postsecondary education, largely by exposing youth to postsecondary school options and environments. For example, one agency offered high school juniors and seniors a one-credit course on postsecondary education preparation. Those enrolled in the course learned about educational opportunities, self-advocacy, accommodation issues, and assistive technology. One agency had a mechanism that allowed local VR offices to develop programs with postsecondary institutions; the extent of the use of this mechanism was unknown beyond the experiences of one county, however.

- Summer engagement programs. Three agencies provided summer programs for transition-age youth that were distinct from their other programming efforts. These were short term (one or two weeks), structured as either day or overnight camps, and emphasized the development of independent living skills as well as education and employment skills. These programs were targeted to youth with specific disorders (such as blindness or physical disabilities) and served a limited number of youth. In addition, intensive school-based transition programs often also had summer components to keep youth engaged in vocational and educational activities, and other programs, such as the independent living and postsecondary programs, also took place during the summer. 
Table 4. Characteristics of VR Agencies on Service Delivery

\begin{tabular}{|c|c|c|c|c|c|c|c|c|}
\hline & \multicolumn{5}{|c|}{ Agencies with High Transition Ratios } & \multicolumn{3}{|c|}{ Agencies with Low Transition Ratios } \\
\hline & Agency A & Agency B & Agency C & Agency D & Agency E & Agency F & Agency G & Agency $\mathrm{H}$ \\
\hline $\begin{array}{l}\text { Secondary School } \\
\text { Programs }\end{array}$ & $\begin{array}{l}7 \text { high schools } \\
\text { serving } 740 \text { total } \\
\text { youth annually }\end{array}$ & $\begin{array}{l}11 \text { to } 15 \text { schools } \\
\text { serving } 400-500 \\
\text { total youth } \\
\text { annually }\end{array}$ & $\begin{array}{l}\text { One program with } \\
6 \text { sites and } 50-60 \\
\text { youth each } \\
\text { annually; one } \\
\text { program with } 14 \\
\text { sites and } 35 \text { youth } \\
\text { each annually }\end{array}$ & & $\begin{array}{l}\text { One program } \\
\text { serving } 41 \\
\text { youth annually }\end{array}$ & $\begin{array}{l}\text { One program } \\
\text { serving } 15 \\
\text { youth per class } \\
\text { and several } \\
\text { classes } \\
\text { annually }\end{array}$ & & $\begin{array}{c}\text { One integrated } \\
\text { high school } \\
\text { program in } 6 \\
\text { high schools } \\
\text { serving } 200+ \\
\text { youth annually; } \\
36 \text { high schools } \\
\text { with specialized } \\
\text { technical } \\
\text { programs }\end{array}$ \\
\hline $\begin{array}{l}\text { Independent Living } \\
\text { Programs }\end{array}$ & & & & & $\begin{array}{l}\text { One program } \\
\text { serving 11-12 } \\
\text { total youth } \\
\text { annually }\end{array}$ & $\begin{array}{l}\text { One program } \\
\text { serving } 12 \text { total } \\
\text { youth annually }\end{array}$ & & \\
\hline $\begin{array}{l}\text { Postsecondary } \\
\text { Education Programs }\end{array}$ & $\begin{array}{c}\text { One program with } \\
2 \text { sites serving } \\
50-60 \text { youth each } \\
\text { annually }\end{array}$ & & $\begin{array}{c}4 \text { programs in } \\
\text { conjunction with } \\
\text { other agencies } \\
\text { (number served } \\
\text { unknown); } \\
\text { counselors with } \\
\text { exclusive } \\
\text { postsecondary } \\
\text { caseloads }\end{array}$ & $\begin{array}{l}\text { One program with } \\
23 \text { sites serving } \\
400 \text { total youth } \\
\text { annually }\end{array}$ & & & $\begin{array}{l}\text { Local } \\
\text { mechanisms for } \\
\text { postsecondary } \\
\text { programs }\end{array}$ & \\
\hline $\begin{array}{l}\text { Summer Engagement } \\
\text { Programs }\end{array}$ & & & $\begin{array}{l}\text { One program with } \\
2 \text { sites serving } 7- \\
20 \text { youth each } \\
\text { annually }\end{array}$ & $\begin{array}{l}\text { One program } \\
\text { serving } 25 \text { youth }\end{array}$ & & $\begin{array}{l}\text { One program } \\
\text { with } 2 \text { sites } \\
\text { serving } 7-10 \\
\text { youth each } \\
\text { annually }\end{array}$ & & \\
\hline $\begin{array}{l}\text { Youth Leadership } \\
\text { Programs }\end{array}$ & $x$ & & $x$ & & & & $x$ & $x$ \\
\hline Benefits Counseling & VR staff & External provider & VR staff & $\begin{array}{l}\text { Both VR staff and } \\
\text { external provider }\end{array}$ & $\begin{array}{l}\text { Both VR staff } \\
\text { and external } \\
\text { provider }\end{array}$ & $\begin{array}{l}\text { External } \\
\text { provider }\end{array}$ & $\begin{array}{l}\text { External } \\
\text { provider }\end{array}$ & $\begin{array}{l}\text { External } \\
\text { provider }\end{array}$ \\
\hline
\end{tabular}

VR = vocational rehabilitation agency. 
- Youth leadership programs. Four agencies conducted leadership programs for youth. These multiday programs typically focused on self-advocacy training, networking, and skill building.

- Benefits counseling. Agencies typically offered benefits counseling, which was generally targeted to individuals receiving SSA disability benefits. However, agencies differed in who delivered the counseling. Four agencies relied entirely on referrals to external providers such as the local Work Incentive Planning and Assistance (WIPA) center or CIL. Two agencies had benefit counselors on staff, though none were transition-specific benefit counselors. Two other agencies had staff available for benefits counseling in some offices, but also utilized external resources to deliver counseling services either in areas without a trained VR counselor (such as rural areas) or for more complex benefits issues.

\section{Service Delivery Features Associated with Transition Ratios}

Agencies with high and low transition ratios differed in three areas in terms of service delivery:

- Intensive, school-based programs. Three agencies with high transition ratios had developed programs in secondary schools that were intensive and served many youth; only one agency with low transition ratios had done so.

- Connecting youth to postsecondary education. Three agencies with high transition ratios conducted programs to inform and expose youth to postsecondary opportunities; just one agency with low transition ratios did so.

- Internal benefits counseling. Four of five agencies with high transition ratios had internal resources to provide benefits counseling services (either wholly or in part), whereas all three agencies with low transition ratios relied on external resources for such services.

\section{Employment}

VR agencies are funded with the purpose of helping eligible people with disabilities prepare for, find, and retain employment. Agency staff reported following best practices with respect to preparing youth for employment, including providing youth with work experiences before graduation and exposing youth to multiple types of work experiences in different fields through internships and job shadowing, to help youth discover likes and dislikes in a low-stakes environment and build realistic expectations for future employment.

\section{Themes Regarding Employment}

All eight agencies offered employment and training programs exclusively for youth and young adults that provided supports of long duration, but they varied in the extent to which these programs were available and the potential number of youth who could receive such services (see Table 5). Note, also, that employment was an aspect of other programs (such as the intensive school-based programs in Table 4) not signified in this table. It is also striking that no agency had developed a specific summer employment program to benefit their youth, though this may have been an aspect of other programs or of programs administered by other organizations. Agency employment and training programs fall into these categories: 
Table 5. Characteristics of VR Agencies on Employment

\begin{tabular}{|c|c|c|c|c|c|c|c|c|}
\hline & \multicolumn{5}{|c|}{ Agencies with High Transition Ratios } & \multicolumn{3}{|c|}{ Agencies with Low Transition Ratios } \\
\hline & Agency A & Agency B & Agency C & Agency D & Agency E & Agency F & Agency G & Agency $\mathrm{H}$ \\
\hline Project SEARCH & $\begin{array}{l}2 \text { sites serving } \\
12-15 \text { youth } \\
\text { each annually }\end{array}$ & $\begin{array}{l}2 \text { sites serving } \\
12-15 \text { youth } \\
\text { each annually }\end{array}$ & & $\begin{array}{l}\text { Multiple sites } \\
\text { serving 8-12 } \\
\text { youth each } \\
\text { annually }\end{array}$ & $\begin{array}{l}\text { Multiple sites } \\
\text { serving } 20 \text { total } \\
\text { youth annually }\end{array}$ & $\begin{array}{l}\text { One site serving } \\
10 \text { total youth } \\
\text { annually }\end{array}$ & $\begin{array}{l}\text { Multiple sites } \\
\text { serving 10-15 } \\
\text { youth each } \\
\text { annually }\end{array}$ & $\begin{array}{l}\text { Multiple sites } \\
\text { serving } 10-12 \\
\text { youth each } \\
\text { annually }\end{array}$ \\
\hline Other Employment Programs & $\begin{array}{l}4 \text { model } \\
\text { employment } \\
\text { sites }\end{array}$ & $\begin{array}{l}\text { Career training } \\
\text { center (over } 200 \\
\text { slots) }\end{array}$ & $\begin{array}{l}\text { Varied job } \\
\text { readiness } \\
\text { programs }\end{array}$ & $\begin{array}{l}\text { Numerous local } \\
\text { employment and } \\
\text { training projects }\end{array}$ & $\begin{array}{l}\text { One program } \\
\text { serving } 20 \text { total } \\
\text { youth annually; } \\
\text { one program } \\
\text { serving } 15 \text { total } \\
\text { youth annually }\end{array}$ & & & $\begin{array}{l}\text { Job coaches in } \\
17 \text { school } \\
\text { districts serving } \\
200+\text { total youth } \\
\text { annually }\end{array}$ \\
\hline Statewide Dedicated Staff & $x$ & $x$ & & $\mathrm{x}$ & $x$ & $x$ & $x$ & $x$ \\
\hline $\begin{array}{l}\text { Regional or Local Dedicated } \\
\text { Staff }\end{array}$ & & $x$ & $x$ & $x$ & $\mathrm{x}$ & $\mathrm{x}$ & & $x$ \\
\hline $\begin{array}{l}\text { Counselors with Business } \\
\text { Development } \\
\text { Responsibilities }\end{array}$ & $x$ & & $x$ & & $\mathrm{x}$ & $x$ & $x$ & \\
\hline
\end{tabular}


- Project SEARCH. Project SEARCH is a nationally-promoted model of employment training that communities can implement locally. These programs provide on-the-job training for a limited number of youth with disabilities in specific employer settings, such as hospital and manufacturing, over a long period of time (such as a school year). These programs are geographically specific, require a long-term commitment from youth, and are often associated with secondary schools. Seven agencies had at least one such project, and four had multiple locations.

- Other employment programs. Most agencies had at least one program other than Project SEARCH that exposed youth to work, though the range of these programs was wide. Agency B offered a career training center for specific vocational skill development, while Agency $\mathrm{H}$ supported a program to staff job developers in several high schools across the state. Other agencies offered more traditional programs to serve youth in a specific area.

We tracked other key features of agencies related to employment and staffing (see Table 5).

- Statewide dedicated staff. Though all but one agency had statewide coordinators to oversee connections with employers, no interviewees identified ways that those staff leveraged business connections specifically for transition-age youth. Instead, the statewide staff worked on job development issues to benefit the agency and customers as a whole. The exceptions involved working with employers for specific transition programs (as with a Project SEARCH site).

- Regional or local dedicated staff. Six agencies had dedicated regional or office-level staff-or contractors - whose primary function was to develop and maintain employer connections and assist with job development for all counselors, including transition counselors.

- Counselors with business development responsibilities. Staff from five agencies reported that their VR counselor's job duties explicitly included developing employer connections. Examples of job duties include maintaining a list of employer contacts, developing relationships with local employers, securing job placements, and soliciting employers to participate in job shadowing events.

\section{Employment Features Associated with Transition Ratios}

Agencies with high and low transition ratios differed in only one employment feature:

- Supporting employment programs other than Project SEARCH. All five agencies with high transition ratios had employment programs available to youth other than Project SEARCH, compared to only one agency with a low transition ratio.

\section{E. Monitoring and Evaluation}

VR agencies can use performance benchmarks and monitoring to track, evaluate, and improve the quality of their services. These tools can be used to identify underperforming counselors and programs, underserved populations, and gaps in service delivery. All state VR agencies are required by the federal government to monitor and report caseload outcome data and to meet specific outcome performance requirements in order to receive federal funding. To ensure quality of service delivery and to meet these performance requirements, agencies may set internal performance 
benchmarks for their counselors. However, there are concerns that youth VR clients typically remain on caseloads longer than adult clients because of school enrollment and longer term training needs. Counselors with dedicated transition caseloads may therefore have poorer outcome performance data than counselors with mixed caseloads or dedicated adult caseloads.

\section{Themes Regarding Monitoring and Evaluation}

We considered these factors related to monitoring and evaluation (see Table 6):

- Performance benchmarks for counselors. All agencies monitored and set performance benchmarks and goals to evaluate the quality and outcomes of services delivered by their VR counselors. A key difference among agencies was whether these benchmarks varied by caseload type. Four agencies developed standards that varied according to a counselor's caseload, either by the individual characteristics of the caseload or by the type of caseload (transition or adult). This approach allows counselors with a high proportion of youth to have benchmarks that may be more aligned with clients they serve. For the other four agencies, all counselors, regardless of the nature of their caseloads, were expected to meet the same goals (such as having a set number or percentage of successful closures each year).

- Monitoring. All agencies conducted some type of transition-specific monitoring, such as tracking youth who received services from a VR counselor, who engaged in a youthspecific program, or (less commonly) who received Social Security benefits.

- Monitoring of transition-age youth. Seven agencies monitored transition-age youth specifically. Common outcomes measured included different phases of transition (such as the percentage returning to high school and entering postsecondary education) or types of youth (such as the percentage of youth with IEPs). One agency developed a monitoring process to track its work with secondary school youth who had not yet formally applied for VR services.

- Monitoring of youth-specific programs. Five agencies specifically monitored the processes and outcomes for their youth programs, in part to track the effectiveness of these programs.

- Monitoring of SSI/SSDI youth. Four agencies specifically monitored outcomes for their youth clients who were receiving SSI or Social Security Disability Insurance (SSDI) benefits.

- Use of data to improve services. In addition to monitoring counselor performance and youth client outcomes, seven agencies used data to identify service gaps and to plan service delivery. For example, two agencies used data to identify counselors not using IEPs or youth not having contacts within the last 30 days. Other examples of using data to improve services included developing report cards on youth and services for each high school, using data to match job opportunities to youth's vocational capabilities, and tracking referral sources. 
Table 6. Characteristics of VR Agencies on Evaluation and Monitoring Approaches

\begin{tabular}{|c|c|c|c|c|c|c|c|c|}
\hline \multirow[b]{3}{*}{$\begin{array}{l}\text { Performance Benchmarks for } \\
\text { Counselors }\end{array}$} & \multicolumn{5}{|c|}{ Agencies with High Transition Ratios } & \multicolumn{3}{|c|}{ Agencies with Low Transition Ratios } \\
\hline & Agency A & Agency B & Agency C & Agency D & Agency E & Agency F & Agency G & Agency H \\
\hline & Varied & Standard & Varied & Varied & Standard & Standard & Varied & Standard \\
\hline \multicolumn{9}{|l|}{ Monitoring } \\
\hline $\begin{array}{l}\text { Monitoring of transition- } \\
\text { age youth }\end{array}$ & $x$ & $x$ & $x$ & $x$ & & $x$ & $x$ & $x$ \\
\hline $\begin{array}{l}\text { Monitoring of youth- } \\
\text { specific programs }\end{array}$ & $x$ & & $x$ & $x$ & $x$ & & & $x$ \\
\hline $\begin{array}{l}\text { Monitoring of SSI/SSDI } \\
\text { youth }\end{array}$ & $x$ & & $x$ & & & $x$ & & $x$ \\
\hline $\begin{array}{l}\text { Use of Data to Improve } \\
\text { Services }\end{array}$ & $x$ & $x$ & $x$ & $x$ & $x$ & & $x$ & $x$ \\
\hline
\end{tabular}

SSDI = Social Security Disability Insurance; SSI = Supplemental Security Income. 
We also asked about concerns regarding RSA monitoring and standards for transition-age youth, and three themes emerged. First, current standards may not apply to the transition population. For example, current measures monitored by RSA include the percentage of individuals with employment outcomes working 35 hours or more a week or with employer-provided insurance. Jobs for youth tend to differ from jobs for adults in key ways, such as lower wages, fewer hours, and fewer fringe benefits, resulting in lower values of these performance measures. This issue may be particularly significant for agencies that serve higher proportions of youth. Additional measures, such as the proportion of youth who enroll in or graduate from postsecondary schools or specific school or agency collaboration metrics, might be more illustrative of agency efforts with youth. Second, VR agency staff seek clarity on the meaning of the term transition-age youth. The term could include individuals enrolled in high school, individuals who begin receiving services while in high school, individuals who ever had an IEP, or all individuals within a certain age range (such as youth under age 25). New changes to the RSA-911 will likely allow RSA and state agencies to address this concern. It may be that different indicators can be applied to different types of VR agency customers (high school age [those 18 or younger], young adults [those 19 to 24], and working-age adults [those 25 and older]). Third, the work that agencies provide to youth and families, particularly school-based work such as information dissemination and transition planning, is not reflected in any standard or metric. It could be important to measure agency efforts with youth who are not yet applicants.

\section{Monitoring and Evaluation Features Associated with Transition Ratios}

Agencies with high and low transition ratios differed in two ways:

- Varied performance benchmarks for counselors. Three of five agencies with high transition ratios had varied benchmarks for counselors, compared to just one agency with low transition ratios.

- Monitoring of youth-specific programs. Four agencies with high transition ratios used data to evaluate their youth programs; we found evidence of data-driven evaluation for youth programs in just one agency with low transition ratios. 
This page has been left blank for double-sided copying. 


\section{CONCLUSION}

This report presents in-depth information on eight state VR agencies regarding their approaches to serving transition-age youth. The information is drawn primarily from interviews with agency staff knowledgeable about transition issues, supplemented with data from the RSA-911 case service records, RSA monitoring reports, and the agencies' annual reports to RSA. Further, we compared the characteristics of agencies that had relatively high and low transition ratios.

Several factors contribute to the findings of this study. The sample included agencies that focused on transition-age youth, and we interviewed multiple staff at various administrative levels who could provide detailed information about the activities in their agencies. We covered a broad range of topics in five key areas. In addition, we used an objective measure of the extent to which agencies served youth, enabling us to differentiate agencies with high and low transition ratios for this population.

There are also several limitations to the study to consider in interpreting the findings. First, the study was limited to eight agencies; though we attempted to include agencies with a range of characteristics, selected agencies could differ from nonselected agencies in important ways, and had we selected different agencies (or included all state agencies), our findings could differ. Second, the interviews included agency staff only; the perceptions of youth and families or community providers could provide different perspectives on agency practices. Third, we grouped agencies with high and low transition ratios based on the results for applicants from 2004 to 2006 but compared the current practices of agencies in the two groups. Though agency practices may have changed during this period, we found that the statistics were largely consistent from that period to 2011. We therefore feel confident that this is not a major concern. Fourth, despite our best efforts, we may have missed some characteristics, such as details on counselor education and training or the use of ancillary staff, that might also be important in serving youth. Fifth, although we present practices that are associated with the transition ratios, the evidence presented is insufficient to conclude that specific practices themselves lead to higher or lower transition ratios; differences might simply reflect the emphasis that the agency places on serving transition-age youth relative to serving others. It may be that the transition ratios themselves lead to one or another practice, or that other factors (such as the importance a community places on transition) affect both.

An important factor to consider in interpreting these findings is that the measures used to differentiate agencies - the transition ratios on application, service receipt, and employment outcomescan be influenced by factors outside an agency's control. The ratios we created are indicative of the extent to which youth with disabilities applied to an agency; the likelihood that youth received services; and, for those served, the likelihood that the cases closed with employment. Several factors may affect these ratios, such as the case mix and characteristics of youth seeking services. The transition ratios may also reflect choices that the agency — and the community it represents - made concerning whom to serve and how, along with the strengths and weaknesses of the service system available to youth and adults with disabilities.

\section{A. Summary of Findings}

The eight agencies had many similarities in how they identified youth with disabilities and provided services to them. Each had staff dedicated to serving youth, counselors assigned to work in specific schools, and processes for in-school work. They had developed multiple-and creative-ways to 
Table 7. Summary of Features Differentiating Agencies with High and Low Transition Ratios

\begin{tabular}{|c|c|c|c|c|c|c|c|c|}
\hline & \multicolumn{5}{|c|}{ Agencies with High Transition Ratios } & \multicolumn{3}{|c|}{ Agencies with Low Transition Ratios } \\
\hline & Agency A & Agency B & Agency C & Agency D & Agency E & Agency F & Agency G & Agency $\mathrm{H}$ \\
\hline \multicolumn{9}{|l|}{ Organization and Collaboration } \\
\hline $\begin{array}{l}\text { State organization placement in education } \\
\text { departments }\end{array}$ & $\mathrm{X}$ & $\mathrm{x}$ & & & $\mathrm{x}$ & & & $\mathrm{x}$ \\
\hline State leadership with transition responsibilities & $\mathrm{X}$ & & & $\mathrm{X}$ & $x$ & & & $x$ \\
\hline More stakeholder collaborations & & $\begin{array}{l}\text { State and } \\
\text { local }\end{array}$ & Local & $\begin{array}{l}\text { State and } \\
\text { local }\end{array}$ & Local & & & Local \\
\hline \multicolumn{9}{|l|}{ Outreach, Application, and Eligibility Processes } \\
\hline Outreach plans and activities that target parents & $\mathrm{x}$ & $\mathrm{x}$ & $x$ & $x$ & & & & \\
\hline Outreach plans and activities for out-of-school youth & $\mathrm{X}$ & & $X$ & $\mathrm{X}$ & $x$ & & & \\
\hline Targeting younger students for transition services & Sophomore & Sophomore & Junior & Junior & Junior & Junior & Senior & Junior $^{\mathrm{a}}$ \\
\hline $\begin{array}{l}\text { Above-median scores for applicants ages } 16 \text { to } 24 \\
\text { who applied by age } 18\end{array}$ & $\mathrm{X}$ & $\mathrm{X}$ & & $\mathrm{X}$ & $\mathrm{X}$ & & & $\mathrm{X}$ \\
\hline $\begin{array}{l}\text { Above-median scores for applicants ages } 16 \text { to } 19 \\
\text { with an IEP }\end{array}$ & $\mathrm{x}$ & & & $\mathrm{x}$ & $x$ & & & \\
\hline $\begin{array}{l}\text { Above-median scores for proportion of case closures } \\
\text { accounted for by transition-age youth }\end{array}$ & $\mathrm{X}$ & $\mathrm{X}$ & & $\mathrm{X}$ & & & & \\
\hline \multicolumn{9}{|l|}{ Service Delivery } \\
\hline Intensive, school-based programs & $x$ & $x$ & $x$ & & & & & $x$ \\
\hline Connecting youth to postsecondary education & $\mathrm{x}$ & & $\mathrm{x}$ & $x$ & & & $x$ & \\
\hline Internal benefits counseling & $\mathrm{X}$ & & $\mathrm{X}$ & $\mathrm{X}$ & $\mathrm{x}$ & & & \\
\hline \multicolumn{9}{|l|}{ Employment } \\
\hline $\begin{array}{l}\text { Supporting employment programs other than Project } \\
\text { SEARCH }\end{array}$ & $\mathrm{x}$ & $x$ & $\mathrm{x}$ & $\mathrm{X}$ & $x$ & & & $x$ \\
\hline \multicolumn{9}{|l|}{ Monitoring and Evaluation } \\
\hline Varied performance benchmarks for counselors & $\mathrm{x}$ & & $x$ & $x$ & & & $x$ & \\
\hline Monitoring of youth-specific programs & $x$ & & $x$ & $\mathrm{X}$ & $x$ & & & $x$ \\
\hline
\end{tabular}

a Senior at the time of the transition ratio analysis.

IEP = individualized education plan. 
conduct outreach to schools and in-school youth. Each had developed programs targeting youth, often in conjunction with one or more community partners. Most recognized that they cannot serve all youth who qualify for education services under IDEA or Section 508.

Despite these similarities, we observed many differentiating features among agencies with high and low transition ratios. As summarized in Table 7, there are 15 such characteristics in the five areas that we considered. Some aspects are less under an agency's control, such as being under a state department of education and being involved in local or statewide stakeholder collaborations. Others are within an agency's control and may also be more easily developed: examples are having state leadership with exclusive transition responsibilities and developing outreach to parents. Finally, some features, although within an agency's control, represent a greater resource cost; these include developing intensive schoolbased programs, enrolling more youth at earlier ages, and implementing programs to connect youth to postsecondary schools.

Also notable are some features not listed in Table 7, though they are considered by experts as key factors in promoting transitions. These include having counselors and staff who exclusively serve transition-age youth, having resource limitations associated with OOS, and offering employment programs and experiences. These factors, though important, may not be relevant to or practiced by the agencies studied. Alternatively, some factors may be necessary but not sufficient to promote higher transition ratios. For example, all agencies, even those with low transition ratios, had employment programs, often with multiple sites. However, many of these programs serve a small number of youth each, usually no more than 15 to 20 individuals. These intensive programs are likely useful for those who attend, but few of an agency's youth are served in this manner.

An overarching concern is whether policymakers should ask or require all agencies to implement some or all of the program features listed in Table 7 as part of their efforts to promote more successful transitions. Transferring policies, programs, and practices requires careful consideration of what is being transferred, the environment and actors involved, and the rationale for the transfer (Benson and Jordan 2011; Shipan and Volden 2012; Stone 1999). What works for one agency may not necessarily work for another, whether it is transplanted entirely or one or more features are omitted or changed. Policymakers should consider the goals they are trying to achieve, both with their transition-age and general populations, along with the environment and resources, before implementing any new policy.

\section{B. Policy Implications}

Several policy implications follow from the current study. First, 15 characteristics or practices were associated with agencies that had high transition ratios. Many of these are similar to best practices cited elsewhere, such as the VR Transition Study or Guideposts for Success. Use of these practices, inasmuch as agencies have control over them, may help youth with disabilities bridge the gap to adulthood. Agencies interested in improving outcomes for youth with disabilities, particularly those with lower transition ratios, may want to consider adopting these practices.

Second, it is possible, and perhaps likely, that it is not one or another specific practice that helps youth, but a combination of factors (such as counselors, programs, and quality monitoring approaches) that together reflect an agency's commitment to serving youth. This commitment might also reflect the community's desires to promote transition or the level of resources to which an agency has access. For instance, the fact that agencies with higher transition ratios have state- or community-level collaborations with various stakeholders on transition issues could result from the community's commitment to serving these youth, which the agency is capitalizing on, but not leading. Our earlier study (Honeycutt et al. 2013) 
showed differences in transition ratios according to the resources available to agencies (the amount of state funding per individual with disability), though this was not a differentiating factor for the eight agencies in this study. That is, agencies with high and low transition ratios had both below- and aboveaverage resources.

A third policy implication involves monitoring. As noted, RSA currently presents metrics for transition-age youth as part of its reports for VR agencies, but those metrics reflect the adult populations that agencies serve. Agency staff seek guidance on the definition of transition-age youth, appropriate measures that reflect the goals and needs of these youth, and standards by which to measure services and success. Recent changes to the RSA-911 data provided by state agencies-on youth educational enrollment, involvement with other providers, and postsecondary education, for example-could potentially be used to develop appropriate outcome measures for this population.

\section{Directions for Future Research}

The current research findings are suggestive of new directions to improve outcomes for youth, and additional research on this topic should focus on establishing better practices through more rigorous evaluations. Current programs serving youth have largely not been tested as to their effectiveness, and agencies are inconsistent in identifying services delivered and tracking outcomes-both in the short and long term-for participants. Any such evaluations will require rigorous evaluation, using random assignment and tracking of long-term outcomes when possible, along with developing a clear model of what, exactly, is being evaluated. An additional research topic that might interest policymakers is to track the extent to which those who first encounter VR as youth return for services in later years. Many staff mentioned that part of their job is marketing to youth so that they know that they can return to an agency for additional services regardless of the outcome of their first VR experience. One sign of successful engagement of youth might be their return to VR agencies throughout their working careers to obtain additional services, coupled with their sustained labor force participation and self-reliance. 


\section{REFERENCES}

Aron, Laudan, and Pamela Loprest. "Disability and the Education System." The Future of Children, vol. 22, no. 1, 2012, pp. 97-122.

Benson, David, and Andrew Jordan. "What Have We Learned from Policy Transfer Research? Dolowitz and Marsh Revisited.” Political Studies Review, vol. 9, 2011, pp. 366-378.

Carter, Erik W., Audrey Trainor, Orhan Cakiroglu, Beth Swedeen, and Laura Owens. "Availability of and Access to Career Development Activities for Transition-Age Youth with Disabilities." Career Development for Exceptional Individuals, vol. 33, no. 1, 2010, pp. 13-24.

Hemmeter, Jeffrey, Jacqueline Kauff, and David Wittenburg. "Changing Circumstances: Experiences of Child SSI Recipients Before and After Their Age-18 Redetermination for Adult Benefits." Journal of Vocational Rehabilitation, vol. 30, September 2009, pp. 201-221.

Honeycutt, Todd, Allison Thompkins, Maura Bardos, and Steven Stern. "State Differences in the Vocational Rehabilitation Experiences of Transition-Age Youth with Disabilities." Disability Research Consortium Working Paper No. 2013-02. Princeton, NJ: Mathematica Policy Research, August 2013.

Loprest, Pamela J., and David C. Wittenburg. "Post-Transition Experiences of Former Child SSI Recipients.” Social Service Review, vol. 81, no. 4, December 2007, pp. 583-608.

Luecking, Richard G., and Nicholas J. Certo. "Integrating Service Systems at the Point of Transition for Youth with Significant Support Needs: A Model That Works.” American Rehabilitation, vol. 27, no. 9, 2003, pp. 2-9.

Luecking, Richard, and David Wittenburg. "Providing Supports to Youth with Disabilities Transitioning to Adulthood: Case Descriptions from the Youth Transition Demonstration." Journal of Vocational Rehabilitation, vol. 30, September 2009, pp. 241-251.

Moreno, Lorenzo, Todd Honeycutt, Stephanie McLeod, and Claire Gill. "Lessons for Programs Serving Transition-Age Youth: A Comparative Analysis of the U.S. and 10 Other Organization for Economic Co-Operation and Development (OECD) Countries." DRC Working Paper 2013-01. Princeton, NJ: Mathematica Policy Research, April, 2013.

Rutkowski, Susie, Maryellen Daston, Debra Van Kuiken, and Erin Riehle. "Project SEARCH: A Demand-Side Model of High School Transition." Journal of Vocational Rehabilitation, vol. 25, no. 2, 2006, pp. 85-96.

Sanford, Christopher, Lynn Newman, Mary Wagner, Renée Cameto, Anne-Marie Knokey, and Debra Shaver. The Post-High School Outcomes of Young Adults with Disabilities up to 6 Years After High School: Key Findings from the National Longitudinal Transition Study-2 (NLTS2) (NCSER 2011-3004). Menlo Park, CA: SRI International, 2011. Available at [www.nlts2.org/reports/].

Shipan, Charles R., and Craig Volden. "Policy Diffusion: Seven Lessons for Scholars and Practitioners." Public Administration Review, vol. 72, no. 6, 2012, pp. 788-796. 
Stone, Diane. "Learning Lessons and Transferring Policy Across Time, Space, and Disciplines." Politics, vol. 19, no. 1, 1999, pp. 51-59.

The Study Group, Inc. "An Assessment of Transition Policies and Practices in State Vocational Rehabilitation Agencies.” Kill Devil Hills, NC: The Study Group, Inc., June 2007.

U.S. Department of Education. "29th Annual Report to Congress on the Implementation of the Individuals with Disabilities Act, 2007, Volume 1.” Washington, DC: U.S. Department of Education, 2010.

U.S. Government Accountability Office. "Students with Disabilities: Better Federal Coordination Could Lessen Challenges in the Transition from High School." Publication No. GAO-12-594. Washington, DC: U.S. Government Accountability Office, July 2012.

Wittenburg, David C., Thomas Golden, and Michael E. Fishman. "Transition Options for Youth with Disabilities: An Overview of the Programs and Policies That Affect the Transition from School." Journal of Vocational Rehabilitation, vol. 17, 2002, pp. 195-206. 

www.mathematica-mpr.com

Improving public well-being by conducting high quality, objective research and data collection

PRINCETON, NJ - ANN ARBOR, MI - CAMBRIDGE, MA - CHICAGO, IL - OAKLAND, CA - WASHINGTON, DC

\section{MATHEMATICA}

Mathematica ${ }^{\circledast}$ is a registered trademark of Mathematica Policy Research, Inc. 